\title{
SPACE IDENTITYDI SEKOLAH DESAIN DAN ARSITEKTUR STUDI KASUS SEKOLAH DISAIN BAUHAUS DAN AA SCHOOL OF ARCHITECTURE LONDON
}

\author{
Anityas DS ${ }^{1}$ Carina $S^{2}$, Gilang ${ }^{3}$ \\ ${ }^{1}$ Universitas Pandanaran, email: tyas@unpand.ac.id \\ ${ }^{2}$ Universitas Pandanaran
}

\begin{abstract}
This paper discusses the spatial identity / spatial identity in a school or university that organizes an architecture study program or department. The problem found is that they do not understand the understanding of the special spatial identity in architecture schools so that it needs to be studied further. The method used in the discussion is a qualitative method with a case study method. The result of research is that spatial identity has a unique meaning and identity. As an architectural school that has a specialization about space. The meaning of spatial identity in architecture and art schools as a place of expression and the symbolic meaning of space. This characterizes the uniqueness of a school of architecture and arts, especially from the case study of the Bauhaus School and the AA School of Architecture, London.
\end{abstract}

Keywords: Social identity, school of architecture, design and architecture

\begin{abstract}
Abstrak
Paper ini membahas tentang space identity/ identitas ruang di sekolah atau universitas yang menyelenggarakan program studi atau jurusan desain dan arsitektur. Permasalahan yang ditemukan adalah belum adanya pemahaman mengenai space identity yang khusus dalam sekolah desain dan arsitektur sehingga perlu dikaji lebih lanjut. Metode yang digunakan dalam pembahasan adalah metode kualitatif dengan metode studi kasus. Hasil dari penelitian ini adalah bahwa space identity memiliki makna yang unik dan memiliki identitas. Sebagai sekolah arsitektur yang memiliki kekhususan dalam hal ruang. Makna dari space identity di sekolah arsitektur dan seni sebagai tempat berekspresi dan makna simbolik ruang. Hal tersebut menjadi ciri keunikan dari sebuah sekolah arsitektur dan seni khususnya dari studi kasus sekolah Bauhaus dan AA school of architecture London.
\end{abstract}

\section{Kata-kunci : space identity, sekolah arsitektur, disain dan arsitektur}

\section{Pendahuluan}

Pada saat ini karya dalam bidang desain dan arsitektur cukup banyak dibahas dalam level internasional, baik berupa konvensi, pameran dan tulisan-tulisan. Sekolah desain dan arsitektur mempunyai konsep desain baik ruang dalam bangunan serta lingkungan dalam sekolah yang berbeda dengan bidang lainnya. Untuk itu dibutuhkan fasilitas yang sesuai dengan standar untuk mendukung membuka wawasan, melatih kemampuan, memicu ide kreatif, inovatif dan inspirasi serta menjaga produktifitas. Fasilitas yang dibutuhkan lebih khusus dan tepat bagi kegiatan dan pengguna yang berkaitan dengan bidang arsitektur, seni dan desain. Fasilitas dalam sekolah desain dan arsitektur tentunya berbeda dengan sekolah dengan bidang yang lain. Di dalam sekolah arsitektur terdapat berbagai fasilitas yang ditujukan untuk kegiatan mahasiswa desain dan arsitektur. Keunikan dari sebuah ruang yang ada dalam sekolah arsitektur dan desain menjadi daya tarik penulisan space identity di sekolah desain dan arsitektur.

Selama ini belum ada paper yang menyatakan tentang space identity di sekolah disain dan arsitektur, sementara ini space identity lebih banyak membahas tentang urban ( perkotaan), terutama untuk mengenali sebuah ruang dan membentuk pengalaman ruang yang mempunyai identitas. Skala urban tentunya lebih makro dan banyak faktor yang mempengaruhinya. Maka pertanyaan penelitian dari paper ini adalah faktor-faktor apa yang berpengaruh terhadap pembentukan space identity di sekolah disain dan arsitektur. Cakupan skala penelitian lebih sempit dan hanya membahasa space identity di dalam sekolah disain dan arsitektur saja.

Tujuan dari pembahasan ini adalah untuk mendapatkan pemahaman tentang space identity di sekolah desain dan arsitektur. Sekolah harus dapat membentuk pelajar dengan mengembangkan ide dan gagasan 
Jurnal Arsitektur AIUR - Vol 4 No 1 Mei 2021

e-ISSN 2685-1490; p-ISSN 2615-1472

yang pernah ada (Upitis, 2004). Maka sekolah arsitektur dan desain harus penuh dengan ide dan gagasan disain yang imajinatif dan luar biasa. Dengan penulisan paper ini maka akan diperoleh identitas ruang dari sebuah sekolah desain dan arsitektur. Tujuan dari paper ini untuk melengkapi teori tentang space identity yang sudah ada.

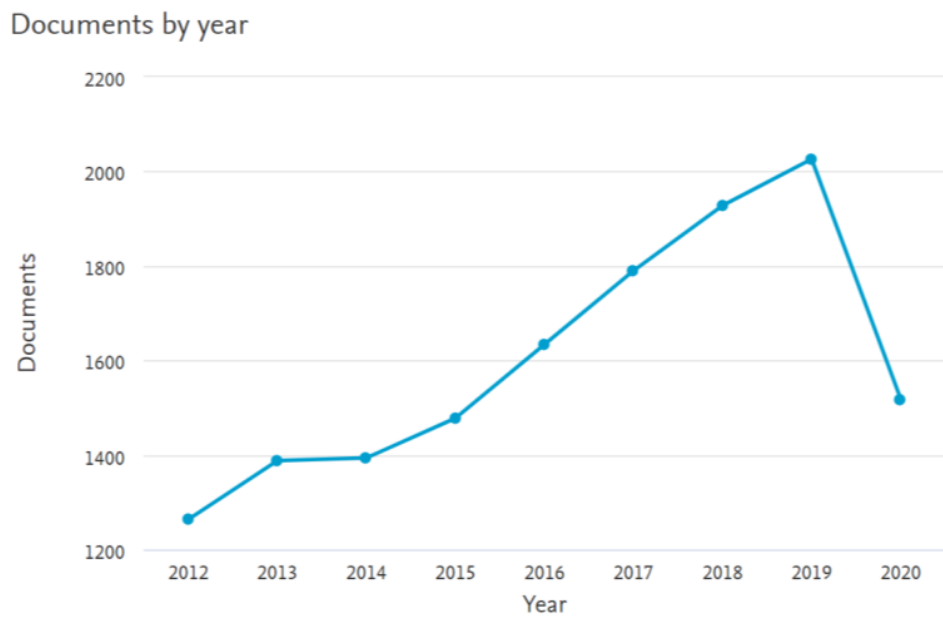

Gambar 1. Documents by year Scopus 2012-2020 Sumber: Scopus

Melihat gambar tersebut diatas yang menjelaskan tentang jumlah dokumen yang membahas space identity dalam kurun waktu 2012-2020, terdapat tren meningkat dari pembahasan tentang space identity. Maka relevansi penulisan topik tersebut tercapai dalam paper ini. Hal ini menjelaskan mengapa topik tentang space identity penting untuk dibahas.

Studi kasus dimaksudkan untuk mengeksplorasi obyek penelitian, menyempitkan fokus penelitian sehingga diperoleh hasil penelitian yang lebih detail. Didalam paper ini disebutkan fokus studi space identity di dua obyek amatan yaitu sekolah desain dan arsitektur Bauhaus dan AA School of Architecture London. Penulis beranggapan kedua sekolah tersebut merupakan sekolah desain dan arsitektur yang cukup berpengaruh baik di negaranya masing-masing maupun di seluruh dunia. Sekolah tersebut sangat terkenal di bidang seni dan teknik, serta mempunyai gaya unik tersendiri terhadap pendidikan seni dan arsitektur. Selain itu kedua sekolah tersebut mempunyai fasilitas yang lengkap dan berorientasi seni. Hal tersebut sangat menarik untuk dikaji dari sisi space identity di sekolah disain dan arsitektur.

\section{Tinjauan Pustaka}

\section{Definisi Space Identity}

Ruang (space) adalah ruang apriori universal ditentukan oleh bentuk aslinya secara khusus. Bentuk adalah keduanya yang merupakan bentuk dari beberapa hal tertentu dan secara universal, adalah kaya akan segala sesuatu yang memberinya bentuk. Ruang adalah universal apriori; bentuk membentuk; itu adalah hubungan yang universal dengan yang khusus. (Pellegrino \& Jeanneret, 2009) Ruang adalah bentuk apriori; itu memungkinkan kita untuk mengetahui realitas eksternal kita ruang kita merepresentasikan kepada diri kita sendiri objek-objek tempat kita bertindak; disitulah kami menentukan bentuknya, besarnya dan hubungan antara mereka (Kant 2000 [1781] (Pellegrino \& Jeanneret, 2009)). Ruang sebagai bentuk struktur apriori dimana tubuh kita sendiri yang bergerak dan menentukan dimana sebuat benda ditempatkan.

Identitas ruang, terutama pada bangunan mengarah pada dampak simbolis yang beragam, perlu dipelajari melalui kerangka kerja yang komprehensif. Biasanya, identitas ruang dipelajari dengan cara denah, komposisi formal, fasad, dll, yang sebenarnya membahas aspek-aspek penting gambar, bukan identitas bangunan. Jadi, sejarah, budaya dan signifikansi sosial dari elemen-elemen ini dan konteks sosial bangunan tetap ada belum dijelajahi dalam studi konvensional. Dalam penelitian Akşehir selain pembentukan citra tersebut elemen, lokasi, situs dan program diusulkan dan didiskusikan dari keragaman ini perspektif. Ini adalah landasan teoritis penting untuk ekspresi niat tentang identitas ruang (Akşehir, 2003) 
Jurnal Arsitektur AIUR - Vol 4 No 1 Mei 2021

e-ISSN 2685-1490; p-ISSN 2615-1472

Pengertian dari space identity atau identitas ruang tidak lepas dari pengertian space dan identitas itu sendiri. Studi mengenai konstruksi space identity telah dilakukan oleh banyak ilmuwan, contohnya Lefebvre (1974) dan kemudian dikembangkan oleh Fairbanks (2003), Boisen (2011), Kalandides (2011), Vela (2013) sedangkan Zenker \& Jacobsen (2015) menunjukkan banyak ilmuwan dari berbagai disiplin ilmu perlu mempelajari tentang pembangunan identitas ruang, baik sebagai branding maupun sebagai upaya konstruksi citra (Aminah, 2018). Space identity memiliki makna ruang yang mengacu pada keunikan suatu tempat sebagai hasil dari interaksi antara fitur fisik dan penggunanya.

Selain lokasi tubuh sendiri, seseorang juga dapat melakukannya invariansi kerangka acuan gravitasi; informasi yang dikumpulkan tentang sebuah objek untuk dijangkau mengandaikan suatu invarian menjadi terlihat dan dapat digunakan di tindakan. Invarian motif dan invarian visual dibangun ke dalam artikulasi lokasi tubuh sendiri dan lokalisasi objek eksternal dalam kaitannya dengan tubuh. Dalam konstruksi invarian ini, gravitasi kerangka acuan dan sistem visualisasi lokal distabilkan dalam model internal, berfungsi sebagai generator bentuk dan persepsi terhadap bentuk. (Pellegrino \& Jeanneret, 2009)

\section{Identitas Arsitektur}

Identitas arsitektural masa kini telah bergeser maknanya dari refleksi lokal lingkungan untuk refleksi abstrak gerakan yang berbeda menggunakan garis, warna, bahan, bentuk, bentuk dan massa sebagai elemen untuk mencapai identitas arsitektur tertentu mereka. Akibatnya, sejumlah besar kota di dunia telah diubah menjadi pemandangan identitas arsitektur yang ramai. (Nooraddin, 2012)

Fungsi semiotik dimulai dengan kapasitas untuk mengantisipasi hubungan antara tindakan dan menyimpulkan satu dari yang lain (Piaget 1978, Pellegrino \& Jeanneret, 2009). Representasi memperluas ruang di luar batas bidang persepsi, dan memungkinkan tidak hanya membayangkan suatu objek dalam ketiadaannya, tetapi menginternalisasi suatu tindakan (fungsi semiotik) dan ekspresi adaptasi tindakan ke objek yang menolaknya ( fungsi pragmatis).

Menurut Kadek Dwi Noorwatha, 2017 dalam melihat karya arsitektur mempunyai aspek struktur, aspek makna simbolis dan aspek fungsi sosial. Selain itu langgam dan proporsi juga mempengaruhi identitas arsitektur suatu bangunan. Unsur yang mempengaruhi identitas arsitektur, dalam hal ini penelitian KD. Noorwatha pada penelitian peciren bebadungan sebagai pembentuk identitas arsitektur di kota Denpasar. Penelitian tersebut menghasilkan adanya unsur yang berpengaruh dalam pembentukan identitas arsitektur yaitu kreatifitas, akseptabilitas dan komformitas (Noorwatha, 2017)

\section{Metode}

Metode yang digunakan dalam pembahasan paper ini adalah metode kualitatif. Metode kualitatif merupakan penelitian yang fleksibel dan sesuai dengan kebutuhan. Metode ini mengandalkan data berupa teks dan gambar serta memiliki keunikan dalam analisis datanya bersumber dari strategi penelitian yang berbeda-beda. (Creswell, 2009)

Metode penelitian yang dipilih adalahvstudi kasus, yaitu meneliti suatu kasus atau fenomena tertentu yang ada didalam masyarakat yang dilakukan secara mendalam untuk mempelajari latar belakang, keadaan, dan interaksi yang terjadi. Studi kasus dilakukan pada satu kesatuan sistem, berupa suatu program, kegiatan, peristiwa, atau sekelompok individu yang ada pada kondisi tertentu. Dalam hal ini yang menjadi studi kasus adalah sekolah arsitektur dan seni yang menjadi pengaruh terhadap dunia arsitektur di dunia. Studi kasus tersebut digunakan untuk mencari variabel dalam space identity di sekolah arsitektur khususnya Bauhaus dan AA School of Architecture.

\section{Metode Pengumpulan Data}

Langkah-langkah pengumpulan data adalah sebagai berikut:

- Mengidentifikasi pertanyaan penelitian untuk kemudian dirumuskan strategi pemecahan masalah atau hipotesa

- Observasi kualitatif terhadap literature baik berupa buku, jurnal dan website resmi. Kemudian mengelompokkan data tersebut menjadi bahan analisa

- $\quad$ Literature review. 
Jurnal Arsitektur AIUR - Vol 4 No 1 Mei 2021

e-ISSN 2685-1490; p-ISSN 2615-1472

\section{Metode Analisis Data}

Analisis data dalam penelitian kualitatif berlangsung bersamaan dengan bagian-bagian dalam penelitian dan pengembangan penelitian. Teks dan gambar dalam literatur dianalisis kemudian diberi pemaknaan. Dalam studi kasus, data yang ada kemudian disandingkan untuk mendapat studi komparasi dari masing-masing studi kasus. Analisis data kemudian dideskripsikan dalam penulisan paper dan dalam kesimpulan adalah temuan dalam penelitian.

\section{Analisis Studi Kasus}

\section{Studi Kasus}

A. Bauhaus Dessau

Bauhaus adalah sebuah sekolah seni dan desain di Jerman yang sangat berpengaruh dalam dunia arsitektur dan desain. Bauhaus merupakan sekolah seni dan desain yang menerapkan kurikulum yang unik, menggabungkan antara seni dan teknik dalam produksi massal. Dalam perkembangannya pula Bauhaus lebih dikenal sebagai sekolah disain yang memiliki gaya seni tersendiri. Site lokasi sekolah yang dibatasi oleh jalan, dengan persimpangan lain tegak lurus dengan yang pertama dan dengan dua sayapnya yang berbatasan dengan lapangan olahraga di dekatnya. Fasade sebagian besar dari sekolah seni dan desain Bauhaus ini merupakan bangunan yang memunculkan ciri modernitas. Setiap fasade dalam bangunan sekolah merespons aktivitas yang terjadi di dalam bangunan dan sekitarnya, bagian depan blok kelas terdiri dari jendela horisontal, yang fungsinya untuk memastikan pencahayaan yang maksimal.

Pembagian zona pada sekolah ini:

1. Bangunan utama adalah akademi seni, yang terdiri dari dua massa bangunan berpotongan, satu bangunan berwarna abu-abu dan yang lainnya putih seperti terlihat lebih transparan. Bangunan ini terkesan seperti melayang dengan adanya warna abu-abu dan putih yang tampak kontras sehingga menjadi daya tarik dalam seluruh kawasan sekolah. Identitas dari bentuk dan warna menjadikan bangunan ini "ikon" dari sekolah Bauhaus.

2. Ruang sosial menjadi persyaratan yang harus ada pada sebuah area sekolah. Dari sekolah Bauhaus kita dapat melihat area sosial tersebut berada diantara ruang lokakarya dan ruang pameran atau ruang studio dan ruang rekreasi untuk pertunjukan musik dan akting dari siswa sekolah Bauhaus.

3. Terdapat apartemen siswa yang terdiri dari 24 apartemen kamar 4 tingkat dan setiap ruangan memiliki balkon pribadi yang terdapat ruang yang berhubungan dengan area luar, dengan balkon yang hanya memuat 1 orang saja. Balkon ini mempunyai fungsi yaitu menambahkan sentuhan ke fasade, sehingga dapat mencapai harmoni dengan adanya pengulangan (repetition).

4. Area kantor : bagian bangunan dua tingkat yang menghubungkan bangunan satu sama lain dan didukung oleh kolom lintas bagian. Elemen ini juga mempunyai akses diantara berbagai bidang sekolah, baik di bawah maupun di atas.

5. Akademi Teknik : terletak di ujung bangunan sekolah, bangunan tersebut lebih sederhana, ditandai dengan jendela horisontal dan tingkat beton pertama terlihat kontras dengan warna putih bangunan lainnya. 


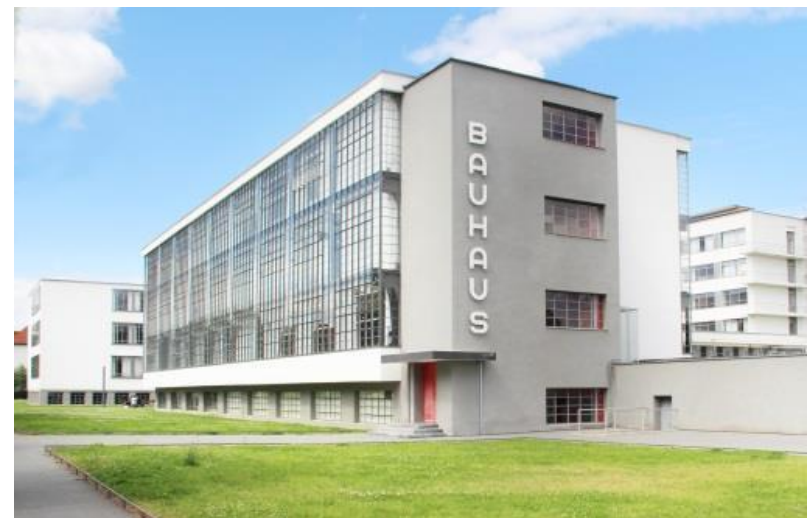

Gambar 2. Gedung Bauhaus dan Isometri Sumber: https://www.archdaily.com/87728/ ad-classics-dessau-bauhaus-walter-gropius

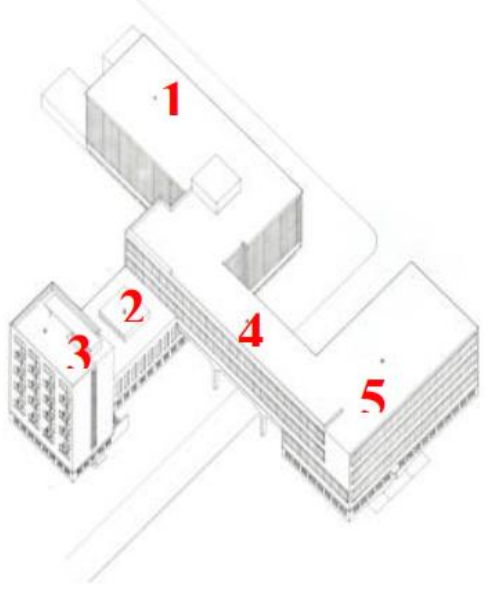

\section{B. AA School of Architecture London}

AA School of Architecture adalah sekolah independen yang didirikan di London, Inggris. Sejak didirikan pada tahun 1847, Asosiasi Arsitektur (AA) telah menjadi rujukan global dalam pendidikan arsitektur serta sebagai pencetus bentuk-bentuk penelitian yang baru dan relevan, wacana kritis, dan praktik radikal. Sekolah ini mencetak karir paling luar biasa di bidang arsitektur dan budaya, dan saat ini siswa dari seluruh dunia dapat mendaftar ke berbagai program akademik yang beragam di sekolah ini. Sekolah Arsitektur, Asosiasi Arsitektur (AA) menawarkan kursus lima tahun yang terdiri dari Program Eksperimental (Tahun 1-3, ARB / RIBA Bagian 1) dan Program Diploma (Tahun 4-5, ARB / RIBA Bagian 2), sebagai serta kursus Praktik Profesional yang terakreditasi RIBA, sembilan program Pascasarjana Diajarkan dan program PhD. Program studi tambahan yang tersedia di sekolah termasuk Kursus Foundation, Sekolah Musim Panas dan Sekolah Kunjungan AA: serangkaian lokakarya intensif yang berlangsung baik di London maupun di seluruh dunia.
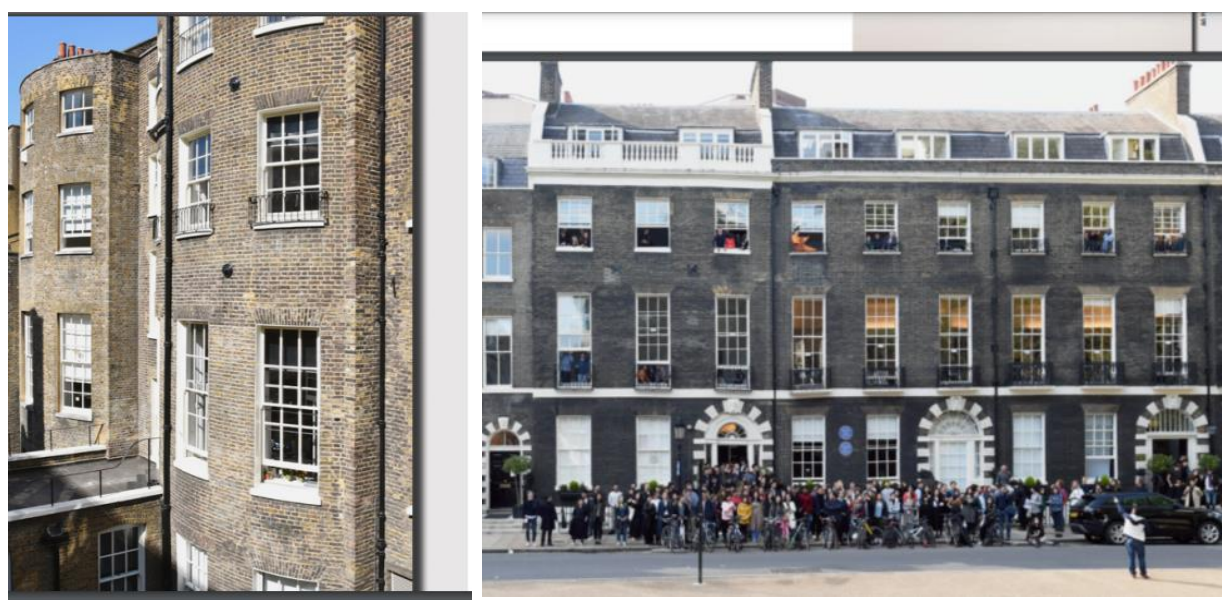

Gambar 3. Tampak bangunan AA School of Architecture

Sumber: (c) Architectural Association School of Architecture 
Jurnal Arsitektur AIUR - Vol 4 No 1 Mei 2021

e-ISSN 2685-1490; p-ISSN 2615-1472

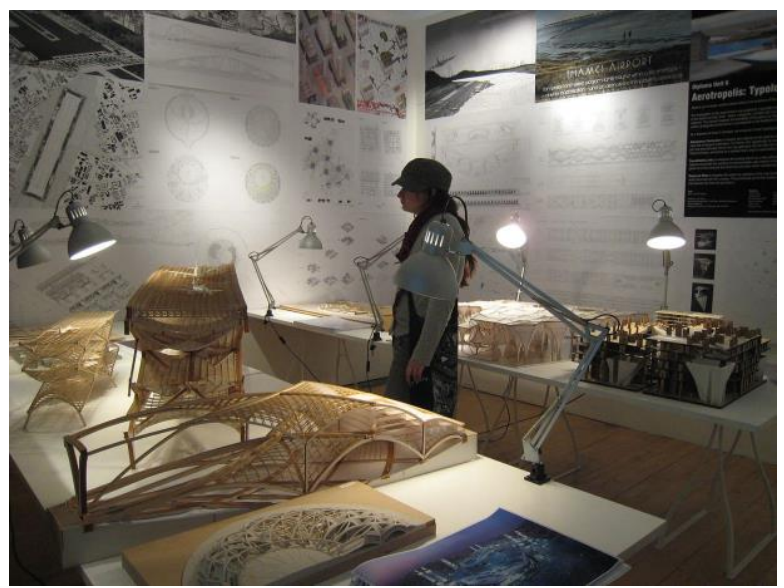

Gambar 4. Fasilitas Studio atau Workshop

Sumber: wikipedia.org/wiki/Architectural_Association_School_of_Architecture,2020

Sekolah memiliki dua kampus. Sebagian besar persediaannya dikirim dari Bedford Square tempat di pusat kota London. Ada juga kampus di Dorset di Taman Hooke, yang sedang dikembangkan sebagai situs untuk mengeksplorasi arsitektur pedesaan, kerajinan konstruksi dan berkelanjutan teknologi kayu. (QAA, 2012)

Dari studi kasus diatas ditemukan faktor-faktor pembentuk identitas ruang dan studi komparatif dari Sekolah Bauhaus dan AA School of Architecture sebagai berikut:

\begin{tabular}{|c|c|c|c|}
\hline & Variabel teori & Sekolah Bauhaus Dessau & AA School of Architecture \\
\hline 1 & Teori bentuk dan komposisi & $\begin{array}{l}\text { Modern, geometri terutama } \\
\text { letak jendela horisontal } \\
\text { yang fungsinya untuk } \\
\text { memasukkan cahaya yang } \\
\text { memadai dalam ruangan. }\end{array}$ & Klasik, material ditonjolkan. \\
\hline \multirow[t]{4}{*}{2} & $\begin{array}{l}\text { Sarana dan Prasarana } \\
\text { Pendidikan pada sekolah } \\
\text { Arsitektur } \\
\text { Fasilitas yang penting: }\end{array}$ & & \\
\hline & 1. Akademi Seni & Menjadi bangunan utama & $\begin{array}{l}\text { Di AA School disebut sebagai } \\
\text { workshop pertukangan dan } \\
\text { workshop seni }\end{array}$ \\
\hline & 2. Publik Space & $\begin{array}{l}\text { Area sosial, digunakan } \\
\text { sebagai ruang rekreasi } \\
\text { bersama }\end{array}$ & $\begin{array}{l}\text { Area sosial, sebagai ruang } \\
\text { rekreasi ada di sekitar } \\
\text { kampus dan taman Hooke } \\
\text { sebagai ruang eksplorasi } \\
\text { kerajinan konstruksi dan } \\
\text { teknologi kayu }\end{array}$ \\
\hline & 3. Studio/workshop & Studio seni & $\begin{array}{l}\text { Workshop konstruksi dan } \\
\text { pertukangan }\end{array}$ \\
\hline 3 & Semiotic function & $\begin{array}{l}\text { Menunjukkan makna } \\
\text { modernitas }\end{array}$ & Menunjukkan makna klasik \\
\hline 4 & Aspek makna simbolis & Simbol modernitas & Simbol klasik modern \\
\hline
\end{tabular}


Jurnal Arsitektur AIUR - Vol 4 No 1 Mei 2021

e-ISSN 2685-1490; p-ISSN 2615-1472

\section{a. Identitas Ruang sebagai tempat berekspresi}

Dari variabel komparatif diatas dapat dimaknakan sebagai identitas ruang di sekolah arsitektur dan desain adalah tersedianya fasilitas terutama studio, sebagai tempat mahasiswa berekspresi. Seperti $A A$ School of Architecture menyediakan studio dan workshop untuk pembuatan maket dan bentuk 3 dimensi lainnya, AA School juga menambah fasilitas taman Hooke sebagai tempat mahasiswa berekspresi dan berkesenian.

Identitas ruang yang terdapat di bangunan Bauhaus Dessau adalah setiap façade sesuai dengan persyaratan kegiatan yang berlangsung di dalam, fasad blok ruang kelas terbentuk dari jendela horisontal, yang fungsinya memastikan cahaya yang memadai. Sementara gedung apartemen sebaliknya, memiliki lubang kecil yang dibangun dengan maksud untuk meningkatkan privasi yang berkesinambungan sesuai dengan kaidah arsitektur. Kemudian Pilar terselip di dalamnya dan menambahkan kantilever yang memungkinkan penopang sudut dihilangkan, sehingga menciptakan pilar terkenal citra transparansi sudut yang menjadi salah satu bagian formal paling khas dari Bauhaus.

\section{b. Makna simbolis ruang}

Makna simbolis seringkali menjadi penting dalam sebuah bangunan atau fasilitas. Makna simbolis ruang sering muncul di berbagai bentuk simbol semiotika seperti yang dikatakan oleh Dewi Parliana (Parliana, 2002):

- The sign vehicle/penyampaian tanda-tanda (what acts as a sign)

- The designation/ penandaan (to what the sign refers)

- The interpretant (the effect on the interpreter by virtue of which a thing is a sign)

Pada studi sekolah arsitektur dengan mengambil studi komparasi antara Bauhaus dan AA School of Architecture, keduanya memiliki makna simbolis ruang dalam bangunannya. Dari bentuk fasade sebetulnya kedua bangunan tersebut tidak menunjukkan simbol tertensu sebagai bangunan sekolah disain dan arsitektur. Penyampaian tanda dan penandaan lebih kepada fasilitas di dalamnya. Antara lain ruang kelas atau akademi seni dan workshop pertukangan. Tanda tersebut akan lebih terlihat jelas dari elemen ruang antara lain workshop dan ruang maket. Di dalamnya terjadi dialog manusia dan benda seni dan arsitektur. Ruang studio, workshop dan ruang maket kemudian dapat disebut sebagai ruang studio atau workshop dengan berbagai aktivitas siswa yaitu menggambar, membuat maket, membuat benda kriya dan lain-lain.

Konsep Simbol: wujud arsitektur juga merupakan media untuk menyampaikan pesan tertentu. Simbol tersebut disebutkan baik itu dalam bentuk indeks, ikon, simbol (contohnya yang terlihat secara fisik dalam sebuah monumen). Pembahasan tentang hal ini walaupun sudah banyak dibahas namun masih membuka peluang lebar untuk diteliti lebih banyak lagi (Y. Ramadin \& Mulyana, 2012)

Dari pernyataan tersebut diatas bahwa wujud arsitektur juga merupakan media penyampai pesan. Ruang-ruang apa saya yang dapat menjadi makna simbolis dari space identity di sekolah disain dan arsitektur. Dari hasil kajian teori dan analisa maka yang menjadi makna ruang tersebut antara lain:

a. Makna ruang yang unik dan berbeda

Dalam studi kasus ruang arsitektur dan seni mempunyai makna unik dan berbeda yaitu ruang studio/ workshop.

b. Simbol-ikon dalam ruang arsitektur

Simbol dapat dinyatakan secara fisik melalui bentuk. Gedung sekolah bauhaus mempunyai kesan ikonik, justru dengan penampilan minimalisnya. Sementara AA School of Architecture menampilkan elemen kriya yang diperlihatkan di setiap sudut sekolah arsitektunya. Konsep simbol ini dalam sekolah arsitektur dan seni adalah cara untuk memperlihatkan ide konsep arsitektural pada bangunan dan elemen lansekap di sekitar bangunan sekolah.

c. Simbol orientasi ruang

Tinjauan arah siswa arsitektur dan seni selalu mengarah kepada ruang studio. Studio sebagai tempat mengekspresikan seni menjadi acuan siswa dalam melakukan aktivitasnya. Dari keseluruhan ruang yang ada pada sekolah arsitektur dan seni, studio merupakan simbol orientasi.

Identitas ruang juga berkaitan dengan kreatifitas, akseptabilitas dan komformitas. Sebagai sekolah arsitektur dan seni, ekspresi dan kreatifitas menjadi penting dalam memahami identitas ruang. Akseptabilitas dan konformitas menjadi faktor pendukung, mengapa siswa dapat bertahan pada ruang tertentu untuk berkreasi. Studio dan workshop merupakan tempat atau ruang yang dipahami sebagai identitas ruang yang mempunyai penerimaan dan kenyamanan untuk siswa berkreasi. 
Jurnal Arsitektur AIUR - Vol 4 No 1 Mei 2021

e-ISSN 2685-1490; p-ISSN 2615-1472

\section{Kesimpulan}

Dari kajian diatas dapat disimpulkan tentang space identity di sekolah desain dan arsitektur. Space identity memiliki makna ruang yang merupakan hasil interaksi manusia dan aktivitasnya yang mengacu kepada tempat yang dihuni memiliki makna yang unik, khusus dan mempunyai identitas. Sebagai sekolah arsitektur yang memiliki kekhususan dalam hal ruang. Arsitektur sebagai bentuk kepemilikan mahasiswa terhadap ilmu tersebut, sangat diperlukan pembentukan pemahaman identitas terhadap ruang dalam sekolah disain dan arsitektur. Makna simbolis ruang diwujudkan pada bangunan dan komposisi ruang dalam bangunan sekolah disain dan arsitektur. Studio merupakan pusat orientasi dari semua ruang yang ada pada program disain dan arsitektur. Arah dan tujuan orientasi menjadi penting dalam pembentukan identitas ruang. Bauhaus dan $A A$ School of Architecture cukup mewakili pembentukan identitas ruang arsitektur dan seni yang mempunyai identitas untuk mencurahkan kreatifitas dan mempunyai makna simbolis ruang sebagai siswa berkreasi.

\section{Ucapan Terima Kasih}

Rangkaian kata terima kasih kami ucapkan kepada Rektor Universitas Pandanaran dan jajarannya serta khususnya Prodi Arsitektur Universitas Pandanaran atas dukungannya dalam pembuatan paper jurnal berjudul Space Identity di Sekolah Arsitektur dan Seni. Terimakasih juga saya ucapkan kepada semua pihak yang telah membantu dalam penulisan paper ini.

\section{Daftar Pustaka}

Akşehir, T. Ş. (2003). A Study on Architectural Elements of Space Identity: Atakule.

Aminah, S. (2018). Construction of space identity: Socio-historical and political dialectics in the globalisation era. Masyarakat, Kebudayaan Dan Politik, 31(2), 140. https://doi.org/10.20473/mkp.v31i22018.140-154

Creswell, J. W. (2009). Creswell's Appreciation of Arabian Architecture. In Muqarnas (Vol. 8). https://doi.org/10.2307/1523157

Nooraddin, H. (2012). Architectural Identity in an Era of Change. Developing Country Studies, 2(10), 81-96. http://www.iiste.org/Journals/index.php/DCS/article/view/3190

Noorwatha, K. D. (2017). Peciren Bebadungan : Studi Identitas Arsitektur langgam Denpasar. May.

Parliana, D. (2002). Persepsi Ruang Publik Melalui Makna Simbolik. November, 1-12.

Pellegrino, P., \& Jeanneret, E. P. (2009). Meaning of space and architecture of place. Semiotica, 2009(175), 269-296. https://doi.org/10.1515/semi.2009.049

QAA. (2012). Architectural Association School of Architecture Review for Educational Oversight by the Quality Assurance Agency for Higher Education (Issue December).

Upitis, R. (2004). School Architecture and Complexity. Complicity: An International Journal of Complexity and Education, 1(1). https://doi.org/10.29173/cmplct8713

Y. Ramadin, T., \& Mulyana, D. (2012). Memahami Makna dan Tanda dalam Objek Visual Arsitektur Ruang Publik. Panggung, 22(1), 83-93. https://doi.org/10.26742/panggung.v22i1.37 